\title{
BECKOVA SEBEPOSUZOVACÍ ŠKÁLA DEPRESIVITY PRO DOSPĚLÉ Recenze metody
}

AUTOR RECENZE: JAROSLAV GOTTFRIED ${ }^{1}$

\begin{tabular}{|c|l|}
\hline \multicolumn{1}{|c|}{ datum vzniku recenze: } & 10. prosinec 2014 \\
\hline 1.1 název nástroje: & Beckova sebeposuzovací škála depresivity pro dospělé \\
\hline zkrácený název: & BDI-II \\
\hline 1.2 původní název: & Beck Depression Inventory-II \\
\hline 1.4 autoři původního testu: & Beck, A.T., Steer, R.A., Brown, G. \\
\hline 1.3 autoři lokální adaptace: & Preiss, M., Vacíŕ, K. \\
\hline 1.7 lokální distributor: & Brno: Psychodiagnostika \\
\hline $1.9 .1 / 1.9 .2$ datum vydání: & 1999 \\
\hline
\end{tabular}

Beckova sebeposuzovací škála pro dospělé (BDI-II, v orig. Beck Depression Inventory-II) je psychodiagnostický nástroj běžně používaný ke zjišt'ování přítomnosti a závažnosti deprese, jakožto momentálního stavu. Široké uplatnění nalézá především v oboru klinické psychologie a neuropsychologie. První verze tohoto nástroje (BDI-I) byla vytvořena Aaronem T. Beckem a jeho spolupracovníky v roce 1961. Jejím primárním účelem bylo kvantitativně změřit intenzitu uživatelovy deprese. BDI-I vykazovala dobré psychometrické vlastnosti a užitečnost u klinických př́padů. Později vyšla upravená verze BDI-IA (Beck, Rush a Emery, 1979), která díky změně některých položek dosáhla vyšší validity i reliability. Uvedená verze měla i některé nedostatky, $\mathrm{z}$ nichž nejvýznamnější představuje nižší souběžná validita s tehdejším DSM-III. U symptomů změn spánku a chuti jídlu byl uživatel tázán pouze na pokles těchto potřeb a nikoliv na případný nárůst. BDI-IA neobsahovala ani žádné položky adresující psychomotorickou aktivitu (Beck, Steer, Ball a Ranieri, 1996). Při př́ležitosti vydání DSM-IV vytvořili Beck, Steer a Brown (1996) novou, v současné době poslední a nejrozšířenější verzi: BDI-II. Postup skórování ani vyhodnocování se nezměnil, přesto dosahovaly osoby vyplňující BDI-II vůči osobám s BDI-IA o přibližně 2 body vyššího celkového skóru deprese. Kromě standardní 21položkové verze existuje ještě verze zkrácená (BDI-SF), která čítá 13

\footnotetext{
${ }^{1}$ Katedra psychologie, Fakulta sociálních studií MU, Joštova 10, 60200 Brno
} 
položek a vykazuje dobré psychometrické vlastnosti, stejně jako vysokou konvergentní validitu s originálem (více viz Furlanetto, Mendlowicz a Romildo, 2005). Tato verze se však administruje se pouze zř́́dka vzhledem k časové nenáročnosti originálu.

BDI-II je sebeposuzující inventář, který uživatel vyplňuje stylem tužka-papír. Je-li to potřeba, může formulář vyplňovat sám administrátor a jeho znění uživateli předčítat. Obsah nástroje se skládá z 21 položek, které jsou zaměřeny na kognitivní, afektivní, motivační a fyziologické symptomy deprese. Každá položka adresuje jeden charakteristický symptom deprese, například pocit neúspěchu, vinu či nechutenství. Odpověd' na položku je zaznamenávána na čtyřbodové škále $0-3$, přičemž každému bodu je zároveň přiřazené jedno tvrzení, kupříkladu 0 - necítím se zklamán sám sebou, 1 - zklamal jsem se sám v sobě, 2 - jsem dost znechucen sám sebou, 3 - nenávidím se. Vyšší číslo indikuje výraznější př́ítomnost symptomu. Uživatel má za úkol označit tvrzení, které nejlépe vystihuje jeho stav během posledních dvou týdnů včetně dne administrace. V případě zvolení více možností u jedné položky se skóruje nejvyšší označená hodnota. Získané skóry u všech 21 položek následně administrátor sečte (rozsah skóru u položky činí 0-3, celkový rozsah výsledného skóru je tudíž 0-63). Z výsledného skóru se poté podle dostupných norem usuzuje na míru deprese uživatele. Doba administrace se pohybuje vrozmezí 5-10 minut a vyhodnocování obvykle nepřesáhne 2 minuty. Ke správné administraci a vyhodnocení je dostačující četba manuálu, interpretaci výsledků by však měla provádět jen osoba zběhlá v používání tohoto nástroje a znalá problematiky deprese, nejlépe klinický psycholog. Škála je určena pro populaci ve věku od 13 do 80 let. Anglický manuál spolu se 100 odpovědními archy lze zakoupit za přibližně 180 dolarů (Ippen a Wong, n.d.). V případě české verze se cenu nepodařilo dohledat, jelikož nástroj není aktuálně prodáván.

BDI-II si mezi psychology získala značnou oblibu, o čemž svědčí i množství překladů. Škála byla přeložena do více než 15 jazyků, z nichž jsou zvláště španělská, arabská, čínská a japonská verze považovány za zdařilé (Ippen a Wong, n.d.). Wang a Gorenstein (2013) ve své přehledné recenzi analyzovali 118 vědeckých článků týkajících se BDI-II a uvádějí důležité psychometrické vlastnosti zmiňovaného nástroje. Průměrné skóre v různých studiích nabývalo hodnot od 5,1 do 38,4. Studie provedené na klinických pacientech podle očekávání získávaly větší průměrné skóre než studie na jiných populacích (studenti, dospělí, atd.). Kvůli nedostatku empirických důkazů o genderové vyváženosti nástroje je vhodné užívat norem pro každé pohlaví zvlášt'.

\section{Anglická verze}

Standardizace originální anglické verze BDI-II proběhla na vzorku 500 pacientů a 120 studentů. Autoři (Beck, Steer a Brown, 1996) uvádějí, že test-retestová reliabilita po 7 dnech činila 0,93 a vnitřní konzistence škály dosáhla hodnoty 0,92 . Ve většině ostatních výzkumů se Cronbachova alfa pohybuje kolem 0,9 (rozsah 0,83-0,96). Souběžnou validitu vykazuje BDI-II středními až silnými korelacemi s množstvím jiných nástrojů pro měření deprese, za všechny např. Center for Epidemiologic Studies of 
Depression (CES-D), Hamilton Depression Rating Scale (HAM-D) nebo Zung Self-Rating Depression Scale (SDS) (více viz Wang a Gorenstein, 2013). Konvergentní validitu dokazují středně silné korelace s nástroji měřícími úzkost (tamtéž), která většinou bývá součástí deprese. Z toho ovšem plyne i nižší diskriminační validita BDI-II mezi depresí a pouhou úzkostí. Řada studií uvádí, že BDI-II také nadhodnocuje depresi u lidí trpících chronickým únavovým syndromem (Brown, Kaplan a Jason, 2011), obezitou (Hayden, Dixon, Dixon a O’Brien, 2010), Huntingtonovou chorobou (Rickards et al., 2011) nebo třeba žloutenkou (Patterson et al., 2011). Důvodem jsou některé somatické projevy podobné symptomům deprese.

Na základě anglické standardizační studie (Beck, Steer a Brown, 1996) byly pro BDI-II navrženy cut-off skóry 0-13 pro minimální nebo žádnou depresi, 14-19 pro mírnou depresi, 20-28 pro střední a 29-63 pro těžkou depresi. Kriteriální validita velmi závisí právě na nastavených cut-off skórech, nebot' skrze ně je přímo ovlivňována senzitivita a specificita nástroje. V naprosté většině studií dosáhla senzitivita BDI-II alespoň hranice 0,7 s hodnotami pohybujícími se nejčastěji v rozmezí 0,8 až 0,9 (Wang a Gorenstein, 2013). Vysoká senzitivita je značnou výhodou BDI-II jakožto screeningového nástroje, ačkoliv je to vykoupeno nižší specificitou (cca 0,7-0,8; Beck, Steer a Brown, 1996; Warmenhoven et al., 2012). Ačkoliv byla metoda původně koncipována pro měření závažnosti deprese, je možné ji použít i coby kvalitní screeningový test. Vzhledem k vyššímu množství falešně pozitivních případů (18 \%; Beck, Steer a Brown, 1996) však není adekvátní metodou pro stanovování klinické diagnózy deprese (více viz Plake a Impara, 2001). Obsahovou validitu není u BDI-II lehké zhodnotit, nebot' metoda nevychází pouze z jednoho teoretického konceptu deprese. Obsahové univerzum položek bylo vytvořeno na základě obecně známých depresivních symptomů, ovšem existují názory (Wang a Gorenstein, 2013), že snahou o přiblížení se diagnostice podle DSM-IV přišlo BDI-II o část svojí senzitivity vůči některým symptomům deprese a tím pádem došlo i k zúžení obsahové validity. Konstruktová validita škály je ověřována především pomocí konfirmační faktorové analýzy. Na toto téma bylo realizováno více výzkumů (např. Steer, Ball, Ranieri a Beck, 1999; Subica et al., 2014) a jako nejlepší se ukázala být dvoufaktorová struktura s kognitivně-afektivním a somatickým faktorem. Některé výzkumy navrhují i trojfaktorový model s kognitivním a afektivním faktorem zvlášt' (Wang a Gorenstein, 2013).

\section{Česká verze}

Českou adaptaci BDI-II vytvořili Preiss a Vacír (1999). Samotný překlad byl čtyřikrát revidován a zkušebně použit na několika pacientech VFN Praha a ÚVN Praha. Žádné další informace o klinickém vzorku či proceduře autoři neuvádějí. Standardizační vzorek pak tvořilo 60 mladých českých mužů, kteří nastoupili na základní vojenskou službu. Průměrné skóre deprese u nich bylo lehce zvýšené ( $m=10,26$; s = 7,02), což autoři přičítají změně denního režimu, která mohla zapř́íčinit zvýšené skóry voblasti somatických symptomů deprese. Zvýšení však může být i důsledkem českého překladu. 
Hlavním úkolem této standardizace bylo identifikovat nesrozumitelné položky. Vzhledem k charakteristikám výzkumného souboru a absenci standardizačního klinického vzorku je nemožné pro českou adaptaci BDI-II stanovit lokální normy. Autoři (tamtéž) se sice ohledně norem odkazují také na jiné české studie, nicméně tyto studie byly prováděny s adaptacemi předchozích verzí BDI, a tudíž je při standardizaci BDI-II nelze využít. Možná i proto se Preiss a Vacíř ve svém manuálu přiklánějí k interpretaci skórů podle Becka, Steera a Browna (1996, viz výše) a ve shodě s nimi navrhují cut-off skór 16/17 s poznámkou, že skórům v rozmezí 10-16 by měla být věnována zvýšená pozornost. Takovéto nekritické přejímání zahraničních norem na českou populaci je však samo o sobě nedostačující. Autoři navíc neuvádějí test-retestovou reliabilitu ani vnitřní konzistenci české verze BDI-II. Senzitivita a specificita taktéž nebyly zjišt'ovány.

\section{Souhrn}

Mezi největší přednosti BDI-II patří zejména jednoduchost, rychlost administrace a vyhodnocování. Zároveň se jedná o světově rozšířený a uznávaný nástroj, který byl přeložen do mnoha jazyků a má normy pro různé populace, ačkoliv je nutné ještě lépe prozkoumat psychometrické vlastnosti české adaptace. Jelikož BDI-II měří depresi jakožto stav, lze ho využít i pro pravidelnou kontrolu nebo detekci změn stavu pacientů. Zaměření se na skóry jednotlivých položek může být navíc užitečným vodítkem při tvorbě celkového obrazu deprese. Nevýhodu představuje vysoká zjevná validita. Uživatel může odpovědi snadno vědomě ovlivnit, a proto by měl administrátor věnovat pozornost extrémně nízkým nebo vysokým celkovým skórům, zvláště existuje-li předpoklad, že by uživatel mohl o svém stavu lhát. V neposlední řadě je důležité mít na paměti, že BDI-II není vhodným nástrojem pro stanovení diagnózy deprese, ale lze ho použít ke screeningu či měření aktuální závažnosti deprese.

Česká adaptace BDI-II (Preiss a Vacír, 1999) ve své podstatě představuje pouze překlad původního znění spolu s hrubým ověřením validity na základě průměrných skórů položek. I když by překlad sám o sobě neměl narušit psychometrické vlastnosti nástroje, je nutné provést důkladnější standardizaci. Bez ní není možné blíže ověřit reliabilitu či validitu nástroje, ani nastavit normy pro českou populaci, což značně omezuje možnosti klinického využití.

\section{Závěr}

BDI-II představuje jednoduchý a psychometricky kvalitní nástroj pro zjišt'ování závažnosti deprese. V př́padě české adaptace však nejsou k dispozici důkazy o validitě ani reliabilitě a při interpretaci výsledků se používají zahraniční normy. Dokud neproběhne důkladnější standardizace, odhad validity a reliability, stanovení lokálních norem a zjištění senzitivity a specificity, je tento nástroj lepší používat pouze pro výzkumné účely. 


\section{Literatura}

Beck, A.T., Rush, A.J., Shaw, B.F., Emery, G. (1979). Cognitive therapy of depression. New York: Guilford.

Beck, A.T., Steer, R.A., Ball, R., Ranieri, W.F. (1996). Comparison of Beck Depression Inventories IA and -II in Psychiatric Outpatients. Journal of Personality Assessment, 67(3), 588-597.

Beck, A.T., Steer, R.A., Brown, G.K. (1996). Manual for the Beck Depression Inventory-II. San Antonio, TX: Psychological Corporation.

Beck, A.T., Ward, C.H., Mendelson, M., Mock, J.E., Erbaugh, J.K. (1961). An inventory for measuring depression. Archives of general psychiatry, 4(6), 561-571.

Brown, M., Kaplan, C., Jason, L. (2011). Factor analysis of the Beck Depression Inventory-II with patiens with chronic fatigue syndrome. Journal of Health Psychology, 17(6), 799-808.

Furlanetto, L.M., Mendlowicz, M.V., Romildo, B.J. (2005). The validity of the Beck Depression Inventory-Short Form as a screening and diagnostic instrument for moderate and severe depression in medical inpatients. Journal of Affective Disorders, 86(1), 87-91.

Hayden, M.J., Dixon, J.B., Dixon, M.E., O’Brien, P.E. (2010). Confirmatory factor analysis of the Beck Depression Inventory in obese individuals seeking surgery. Obesity Surgery, 20, 432439.

Ippen, C. G., Wong, C. (n.d.). Beck Depression Inventory-Second Edition. Staženo 7. 10. 2014 z http://www.nctsnet.org/content/beck-depression-inventory-second-edition.

Patterson, A.L., Morasco, B.J., Fuller, B.E., Indest, D.W., Loftis, J.M., Hauser, P. (2011). Screening for depression in patients with hepatitis $\mathrm{C}$ using the Beck Depression Inventory-II: do somatic symptoms kompromise validity? General Hospital Psychiatry, 33, 354-362.

Plake, B. S., Impara, J. C. (2001). The fourteenth mental measurements yearbook. Buros Institute of Mental Measurements, University of Nebraska-Lincoln.

Preiss, M., Vacíř, K. (1999). BDI-II. Beckova sebeposuzovací škála pro dospělé. Brno: psychodiagnostika.

Rickards, H., De Souza J., Crooks, J., van Walsem, M.R., van Duijn, E., et al. Discriminant analysis of Beck Depression Inventory and Hamilton Rating Scale for Depression in Huntington's disease. Journal of Neuropsychiatry and Clinical Neurosciences, 23, 399-402.

Steer, R.A., Ball, R., Ranieri, W.F., Beck, A.T. (1999). Dimensions of the Beck Depression Inventory-II in clinically depressed outpatients. Journal of Clinical Psychology, 55(1), 117128.

Subica, A.M., Fowler, J.C., Elhai, J.D., Frueh, B.C., Sharp, C., et al. (2014). Factor structure and diagnosis validity of the Beck Depression Inventory-II with adult clinical inpatients: comparison to gold-standard diagnostic interview. Psychological Assessment.

Wang, Y.P., Gorenstein, C. (2013). Psychometric properties of the Beck Depression Inventory-II: a comprehensive review. Revista Brasileira de Psiquiatria, 35, 416-431.

Warmenhoven, F., van Rijswijk, E., Engels, Y., Kan, C., Prins, J., van Weel, C., et al. (2012). The Beck Depression Inventory (BDI-II) and a single screening question as screening tools for depressive disorder in Dutch advanced cancer patients. Supportive Care in Cancer, 20(2), 319-324. 
Podpořeno z projektu OPVK:

INZA - Inovací bakalářských studijních programů k lepší zaměstnatelnosti, CZ.1.07/2.2.00/28.0238

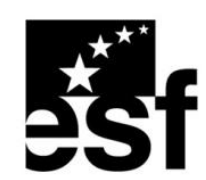

evropský fond $v$ ČR
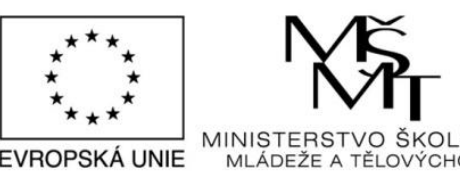

MINISTERSTVO ŠKOLSTVÍ,

MLÁDEŽE A TĚLOVÝCHOVY

INVESTICE DO ROZVOJE VZDĚLÁVÁNÍ

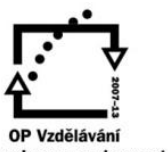

OP Vzdélávání
konkurenceschopnos

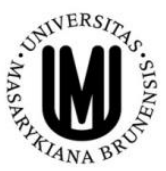

INVESTICEDOROZVOJE VZDËU 


\section{MODEL RECENZE PODLE EFPA PRO POPIS \\ A HODNOCENÍ PSYCHOLOGICKÝCH TESTŮ \\ FORMULÁŘ RECENZE TESTU A POZNÁMKY PRO \\ RECENZENTY ${ }^{1}$}
Toto je lokální úprava dokumentu pro účely publikace v časopise Testfórum.
Originální český překlad je k dispozici na stránkách EFPA
(www.efpa.eu/download/505cd9db4144ecb16174087909c9cd6d).

Od uživatelů tohoto dokumentu a jeho obsahu žádá EFPA, aby uznali tento zdroj prostřednictvím následujícího textu:

"Kritéria pro recenzi testu podle EFPA do značné míry vychází z formy a obsahu kritérií pro recenze testů Britské psychologické společnosti (BPS) a kritérií vytvořených Komisí pro testové záležitosti (COTAN) Holandské asociace psychologu (NIP). Dave Bartram a Patricia Lindley původně vyvinuli kritéria BPS a recenzní procedury pro UK Employment Service a později rozšírili jejich používání pro celou BPS. Arne Evers připravil k vydání nizozemský system posuzování kvality testů.

EFPA je vděčná BPS a NIP za svolení použít jejich kritéria jako základ pro vytvoření evropského modelu. EFPA je také vděčná Davu Bartramovi, Arnu Eversovi a Patricii Lindley za jejich přispění $k$ vývoji tohoto modelu. Veškerá intelektuální vlastnická práva původních kritérií podle BPS a NIP jsou nadále uznávána a náleží těmto orgánům."

\footnotetext{
1 Tento dokument byl vytvořen z několika zdrojů, včetně Hodnotícího formuláře pro recenzi testu používaného v BPS (NPAL a Řídící komise pro testové standardy při BPS - Steering Committee on Test Standards), Španělského dotazníku pro hodnocení psychometrických testů (Španělská psychologická asociace) a Systému pro posuzování kvality testu (Komise pro testování Holandské asociace psychologů). Některé části byly adaptovány se svolením z dokumentu: BPS Books Reviews of Level B Assessment Instruments for use in Occupational Assessment, Notes for Reviewers: Version 3.1. December 1998: Copyright (C) NPAL, 1989, 1993, 1998.

2 Současná verze je spojením dvou oddělených dokumentů (Formuláře recenze a Poznámek pro recenzenty). Obsah byl navíc uspořádán a doplněn na základě jeho používání recenzenty online testů v BPS.
} 


\section{Část 1:}

Popis nástroje: Obecné informace a klasifikace

\begin{tabular}{|c|c|c|}
\hline & Recenzent 1: & Bc. Jaroslav Gottfried \\
\hline & Recenzent 2: & \\
\hline & Konzultující editor: & Mgr. Hynek Cígler \\
\hline & Vedoucí editor: & Mgr. Hynek Cígler \\
\hline & $\begin{array}{l}\text { Vedoucí editor aktualizace: } \\
\text { (pouze v př́padě aktualizací) }\end{array}$ & \\
\hline & $\begin{array}{l}\text { Editor aktualizace: } \\
\text { (pouze v př́padě aktualizací) }\end{array}$ & \\
\hline & Datum vzniku této recenze: & 10. 12.2014 \\
\hline 1.1 & Název nástroje (lokální verze): & $\begin{array}{l}\text { Beckova sebeposuzovací škála depresivity } \\
\text { pro dospělé }\end{array}$ \\
\hline & Zkrácená verze názvu testu: & BDI-II \\
\hline 1.2 & $\begin{array}{l}\text { Původní název testu (pokud je lokální } \\
\text { verze adaptací): }\end{array}$ & Beck Depression Inventory-II \\
\hline 1.4 & Autoři původního testu: & Beck, A.T., Steer, R.A., Brown, G. \\
\hline 1.3 & Autoři lokální adaptace: & Preiss, M., Vacíř, K. \\
\hline 1.7 & Lokální distributor/vydavatel testu: & Brno: Psychodiagnostika \\
\hline 1.8 & $\begin{array}{l}\text { Vydavatel původní verze testu (pokud je } \\
\text { jiný než současný distributor/vydavatel): }\end{array}$ & San Antonio: Pearson \\
\hline 1.9 .1 & Datum vydání současné revize/vydání: & 1996 \\
\hline 1.9 .2 & $\begin{array}{l}\text { Datum vydání adaptace pro lokální } \\
\text { užívání: }\end{array}$ & 1999 \\
\hline 1.9 .3 & Datum vydání původního testu: & 1961 \\
\hline
\end{tabular}




\section{Obecný popis nástroje}

BDI-II je sebeposuzující inventář, který uživatel vyplňuje stylem tužka-papír. Je-li to potřeba, může formuláŕ vyplňovat sám administrátor a jeho znění uživateli předčítat. Obsah nástroje se skládá z 21 položek, které jsou zaměřeny na kognitivní, afektivní, motivační a fyziologické symptomy deprese. Každá položka adresuje jeden charakteristický symptom deprese, např́klad pocit neúspěchu, vinu či nechutenství. Odpověd’ na položku je zaznamenávána na čtyřbodové škále $0-3$, přičemž každému bodu je zároveň přiřazené jedno tvrzení, kupříkladu 0 - necítím se zklamán sám sebou, 1 - zklamal jsem se sám v sobě, 2 - jsem dost znechucen sám sebou, 3 nenávidím se. Vyšší číslo indikuje výraznější přítomnost symptomu. Uživatel má za úkol označit tvrzení, které nejlépe vystihuje jeho stav během posledních dvou týdnů včetně dne administrace. V př́ípadě zvolení více možností u jedné položky se skóruje nejvyšší označená hodnota. Získané skóry u všech 21 položek následně administrátor sečte (rozsah skóru u položky činí 0-3, celkový rozsah výsledného skóru je tudíž 0-63). Z výsledného skóru se poté podle dostupných norem usuzuje na míru deprese uživatele. Doba administrace se pohybuje v rozmezí 5-10 minut a vyhodnocování obvykle nepřesáhne 2 minuty. Ke správné administraci a vyhodnocení je dostačující četba manuálu, interpretaci výsledků by však měla provádět jen osoba zběhlá v používání tohoto nástroje a znalá problematiky deprese, nejlépe klinický psycholog. Škála je určena pro populaci ve věku od 13 do 80 let.

\section{Část 2:}

Klasifikace

\begin{tabular}{|c|c|c|}
\hline 1.10 .1 & Obsahová doména & $\begin{array}{ll} & \text { Školní schopnosti } \\
\square & \text { Všeobecné schopnosti } \\
\square & \text { Verbální schopnosti } \\
\square & \text { Numerické schopnosti } \\
\square & \text { Prostorové schopnosti } \\
\square & \text { Neverbální schopnosti } \\
\square & \text { Rychlost vnímání } \\
\square & \text { Pamět' } \\
\square & \text { Manuální zručnost } \\
\square & \text { Osobnost - Rys } \\
\square & \text { Osobnost - Typ } \\
\square & \text { Osobnost - Stav } \\
\square & \text { Kognitivní styly } \\
\square & \text { Motivace } \\
\square & \text { Hodnoty } \\
\square & \text { Zájmy } \\
\square & \text { Přesvědčení } \\
\square & \text { Poruchy a patologie } \\
\square & \text { Skupinové procesy } \\
\square & \text { Rodina } \\
\square & \text { Organizace, její fungování, agregovaná } \\
\text { měření, klima atd. } \\
\square \text { Školní nebo výchovné funkce } \\
\square \text { Jiné: }\end{array}$ \\
\hline
\end{tabular}




\begin{tabular}{|c|c|c|}
\hline 1.10 .2 & $\begin{array}{l}\text { Zamýšlená(é) nebo hlavní oblast(i) } \\
\text { použití. }\end{array}$ & $\begin{array}{ll}\bigotimes & \text { Klinická psychologie } \\
\bigotimes & \text { Neuropsychologie } \\
\square & \text { Forenzní psychologie } \\
\square & \text { Psychologie výchovy a vzdělávání } \\
\square & \text { Psychologie práce a personalistika } \\
\square & \text { Poradenství, doporučení, vedení a volba } \\
& \text { povolání } \\
\square & \text { Psychologie zdraví, životní styl a životní } \\
& \text { spokojenost } \\
\square & \text { Sporty a volný čas } \\
\square & \text { Jiné: }\end{array}$ \\
\hline 1.10 .3 & $\begin{array}{l}\text { Zamýšlený způsob použití } \\
\text { (podmínky, za jakých byl nástroj } \\
\text { standardizován a validizován) }\end{array}$ & $\begin{array}{l}\text { Nesupervidovaná administrace bez } \\
\text { kontroly nad identitou respondenta a bez } \\
\text { úplné kontroly nad podmínkami } \\
\text { administrace (např. volně pŕístupný test } \\
\text { na internetu, test dostupný ke koupi v } \\
\text { knihkupectví). } \\
\text { Kontrolovaný nesupervidovanou } \\
\text { administrcí. Kontrola nad podmínkami } \\
\text { (čas atd.) a určitá kontrola nad identitou } \\
\text { uživatele testu (např. testy } \\
\text { administrované přes internet, ale pouze } \\
\text { známým osobám - př́stup omezený } \\
\text { heslem). } \\
\text { Supervidovaná a kontrolovaná } \\
\text { administrace. Administrace testu pod } \\
\text { kontrolou kvalifikovaného adminitrátora } \\
\text { nebo dohlížitele. } \\
\text { řízená administrace. Administrace testu } \\
\text { prováděná pouze přes určená testovací } \\
\text { centra (např. programy hodnocení licencí } \\
\text { a certifikace). }\end{array}$ \\
\hline $\begin{array}{l}1.10 .4 \\
\end{array}$ & $\begin{array}{l}\text { Popis populací, pro které je test } \\
\text { určen: }\end{array}$ & Lidé ve věku 13-80 let. \\
\hline 1.10 .5 & $\begin{array}{l}\text { Počet škál a krátký popis } \\
\text { proměnné nebo proměnných } \\
\text { měřených nástrojem }\end{array}$ & $\begin{array}{l}\text { Škála depresivity: každá položka představuje } \\
\text { jednu dimenzi, např. ztráta chuti k jídlu, } \\
\text { pesimismus, pocit viny. Za účelem klinického } \\
\text { prozkoumání konkrétních symptomů } \\
\text { depresivity se také může interpretovat každá } \\
\text { položka zvlášt'. }\end{array}$ \\
\hline 1.11 & Formát položek & $\begin{array}{ll} & \text { Otevřený } \\
\square & \text { Mnohonásobná volba, alternativy na stejné } \\
\text { škále } \\
\square \text { Bipolární adjektiva } \\
\bigotimes \quad \text { Likertovy ratingy (škály) } \\
\square & \text { Nucená volba, alternativy na smíšených } \\
\text { škálách (ipsativní) - vysvětlení viz } \\
\text { Poznámky } \\
\square \text { Mnohonásobná volba, alternativy na } \\
\text { smíšených škálách (ipsativní) - vysvětlení } \\
\text { viz Poznámky } \\
\square \text { Sady párủ adjektiv (sémantický } \\
\text { diferenciál), smíšené škály (ipsativní) } \\
\square \quad \text { Jiné: }\end{array}$ \\
\hline
\end{tabular}




\begin{tabular}{|c|c|c|c|c|}
\hline 1.12 & Počet položek testu: & \multicolumn{3}{|c|}{21} \\
\hline 1.13 & Způsob(y) administrace: & \multicolumn{3}{|c|}{$\begin{array}{ll} & \text { Interaktivní individuální administrace } \\
\square & \text { Supervidovaná skupinová administrace } \\
\square & \text { Počítačová lokálně nainstalovaná aplikace } \\
& \text { - pod supervizí/dohledem } \\
\square & \text { Počítačová aplikace na webu - pod } \\
& \text { supervizí/dohledem } \\
\square & \text { Počítačová lokálně nainstalovaná aplikace } \\
& \text { - bez supervise/testování sebe } \\
\square & \text { Počítačová aplikace na webu - bez } \\
\text { supervize/testování sebe } \\
\square & \text { Jiné: }\end{array}$} \\
\hline 1.14 & Způsob odpovídání: & $\begin{array}{l}\bigotimes \\
\bigotimes \\
\square \\
\square \\
\square\end{array}$ & \multicolumn{2}{|c|}{$\begin{array}{l}\text { Ústní rozhovor } \\
\text { Papír a tužka } \\
\text { Manuální operace } \\
\text { Na počítači } \\
\text { Jiné: }\end{array}$} \\
\hline 1.15 & 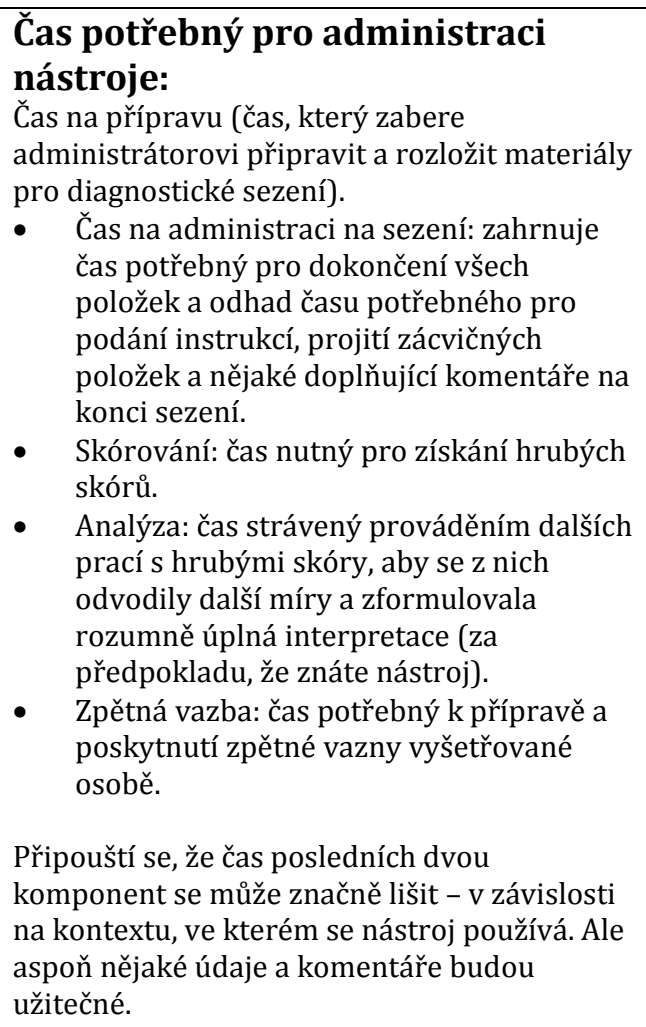 & & $\begin{array}{l}\text { Příprava: } \\
\text { Administrace: } \\
\text { Skórování: } \\
\text { Analýza: } \\
\text { Zpětná vazba: }\end{array}$ & $\begin{array}{l}--- \\
5-10 \\
2 \\
2 \\
5\end{array}$ \\
\hline 1.16 & $\begin{array}{l}\text { Jsou k dispozici různé formy } \\
\text { nástroje? }\end{array}$ & & $\begin{array}{l}\text { Ano, v prrípadě č } \\
\text { verze pro muže } \\
\text { nimi jsou pouze }\end{array}$ & $\begin{array}{l}\text { eské adaptace existuje } \\
\text { a pro ženy. Rozdíly mezi } \\
\text { gramatického charakteru. }\end{array}$ \\
\hline
\end{tabular}




\section{Č́st 3:}

\section{Měření a skórování}

\begin{tabular}{|c|c|c|}
\hline 1.17 & Procedura skórování testu: & 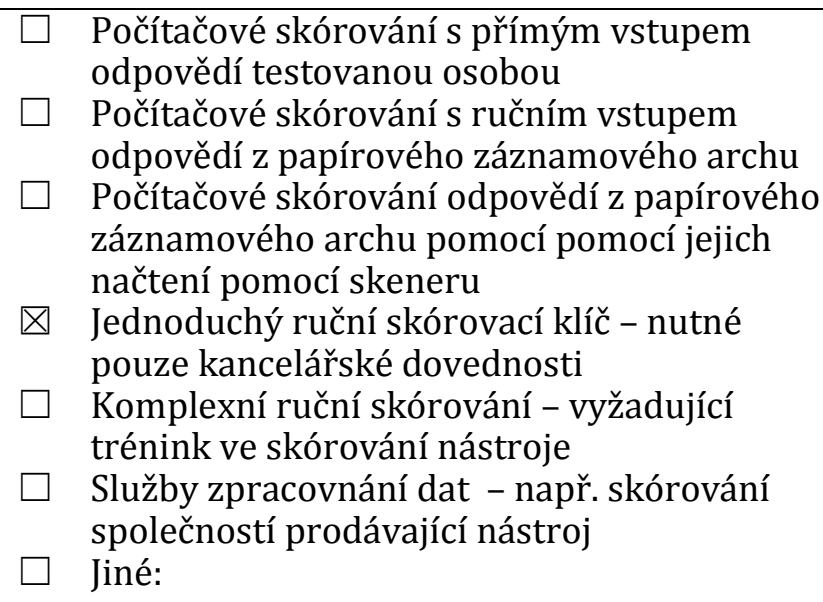 \\
\hline 1.18 & Skóry: & $\begin{array}{l}21 \text { položek s odpověd'mi na škále } 0-3 \text {. Sečtením } \\
\text { odpovědí vzniká výsledný skór v rozmezí } 0-63 \text {. }\end{array}$ \\
\hline 1.19 & $\begin{array}{l}\text { Transformace skóru na standardní } \\
\text { skóry: }\end{array}$ & $\begin{array}{l}\square \quad \begin{array}{l}\text { Normalizovaná - skóry se získají použitím } \\
\text { normalizační tabulky }\end{array} \\
\square \quad \text { Nenormalizovaná - skóry se získají lineární } \\
\text { transformací } \\
\square \quad \text { Jiné: } \\
\quad \begin{array}{l}\text { Neprovádí se transformace na } \\
\text { standardní skóry. Interpretace výsledků } \\
\text { probíhá na základě hrubých skórů. }\end{array} \\
\quad\end{array}$ \\
\hline 1.20 & Použité škály & $\begin{array}{l}\text { Skóry založené na percentilech } \\
\square \quad \text { Centily } \\
\square \quad \text { 5-stupňová klasifikace: centilové rozdělení } \\
\text { 10:20:40:20:10 } \\
\square \quad \text { Decily a další klasifikace založené na stejném } \\
\text { počtu percentilů } \\
\text { Standardní skóry } \\
\square \quad \text { z-skóry } \\
\square \quad \text { IQ deviační kvocienty IQ atd. } \\
\text { (např. M=100, SD=15 pro Weschlerův test) } \\
\square \quad \text { Přijímací testy na VŠ } \\
\text { (např. test SAT M=500, SD=100; GRE atp.) } \\
\square \quad \text { steny, staniny, C skóry } \\
\square \quad \text { T-skóry } \\
\square \quad \text { Jiné: } \\
\quad \text { Neprovádí se transformace na } \\
\text { standardní skóry. Interpretace výsledků } \\
\text { probíhá na základě hrubých skórŭ. }\end{array}$ \\
\hline
\end{tabular}




\section{Část 5:}

\section{Nabídka, podmínky a náklady}

Tato část definuje, co vydavatel poskytne, komu, za jakých podmínek a za jaké ceny. Definuje podmínky kladené dodavatelem a týkající se toho, kdo smí a kdo nesmí získat materiál nástroje. Pokud jedna z možností neodpovídá podmínkám nabídky, doplňte popis relevantních podmínek.

\begin{tabular}{|c|c|c|}
\hline 1.23 & $\begin{array}{l}\text { Dokumentace poskytovaná } \\
\text { distributorem jako součást } \\
\text { testového balíku }\end{array}$ & $\begin{array}{ll}\square & \text { Uživatelský manuál } \\
\bigotimes & \text { Technický (psychometrický) manuál } \\
\square & \text { Doplňkové technické informace a aktualizace } \\
\text { (např. lokální normy, lokální validizační studie } \\
\text { atd.) } \\
\square \text { Rozšiřující informace v podobě knih a článků k } \\
\text { tématu } \\
\square \text { Kombinace výše uvedených (uved’te) }\end{array}$ \\
\hline 1.24 & Metody publikace & $\begin{array}{ll} & \text { Papír } \\
\square & \text { PC - Diskety } \\
\square & \text { PC - CD/ROM } \\
\square & \text { Download z internetu } \\
\square & \text { Živý internet (nástroj pracuje v internetovém } \\
\text { prohlížeči) } \\
\square \text { Jiné: }\end{array}$ \\
\hline 1.25 .1 & $\begin{array}{l}\text { Počáteční náklady. } \\
\text { Cena kompletní sady materiálı̊ (všechny manuály a } \\
\text { další material nutný k aspoň jedné zkušební } \\
\text { administraci). Kolik uchazečú lze vyšetřovat pomocí } \\
\text { materiálů získaných za počáteční náklady, kde tyto } \\
\text { náklady zahrnují materially pro opakované vyšetření. }\end{array}$ & Neznámé - metoda není v současnosti vydávána. \\
\hline 1.25 .2 & Opakující se náklady: & Neznámé - metoda není v současnosti vydávána. \\
\hline 1.26 .1 & $\begin{array}{l}\text { Ceny za zprávy generované } \\
\text { softwarem nainstalovaným } \\
\text { uživatelem: }\end{array}$ & \\
\hline 1.26 .2 & $\begin{array}{l}\text { Ceny za vyhotovení zprávy zaslené } \\
\text { prostřednictvím pošty/faxu: }\end{array}$ & \\
\hline 1.26 .3 & $\begin{array}{l}\text { Ceny za vyhotovení zprávy zaslené } \\
\text { prostřednictvím internetové služby: }\end{array}$ & \\
\hline 1.27 & $\begin{array}{l}\text { Ceny za další služby a zpracování } \\
\text { dat: opravy nebo vývoj } \\
\text { automatických zpráv: }\end{array}$ & \\
\hline
\end{tabular}




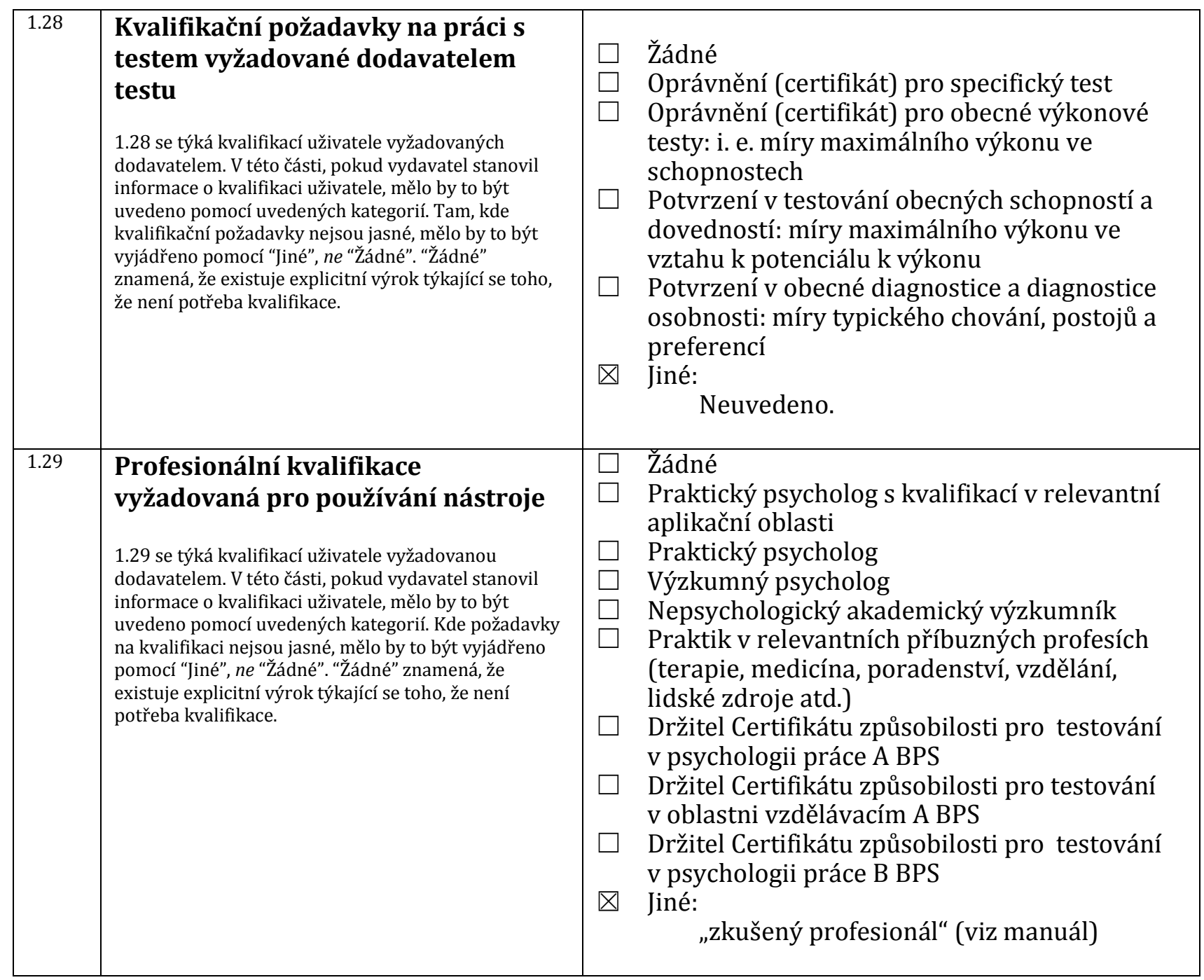


Část 6:

\section{Hodnocení testových materiálů}

\section{Vysvětlení hodnocení}

V následujících částech jsou celková posouzení adekvátnosti informací týkajících se validity, reliability a norem zobrazeny automaticky tučně.

Jakýkoli nástroj $s$ jedním nebo více posouzeními 0 nebo 2 týkajícími se atributů považovaných za kritické pro bezpečné používání nástroje, by neměl být považován za nástroj, který splňuje minimální standardy.

\begin{tabular}{|c|c|c|c|}
\hline $\begin{array}{l}\text { Vstup na posuzovacím } \\
\text { formuláři }\end{array}$ & $\begin{array}{l}\text { Posouzení podle } \\
\text { standardi̊ EFPA }\end{array}$ & $\begin{array}{c}\text { Reprezentace recenze } v \\
\mathrm{UK}\end{array}$ & Vysvětlení \\
\hline [n/a] & {$[\mathrm{n} / \mathrm{a}]$} & [n/a ] & $\begin{array}{l}\text { Tento atribut není u tohoto } \\
\text { nástroje použitelný }\end{array}$ \\
\hline $\mathbf{0}$ & {$[-]$} & [None] & $\begin{array}{c}\text { Není možné posoudit jako ne } \\
\text { nebo nedostatek } \\
\text { poskytnutých informací }\end{array}$ \\
\hline 1 & {$[-1]$} & {$\left[\begin{array}{ll}* & ]\end{array}\right.$} & Neadekvátní \\
\hline 2 & & {$\left[\begin{array}{ll}* * & ]\end{array}\right.$} & NYNÍ NEPOUŽÍVÁNO \\
\hline 3 & {$\left[\begin{array}{ll}0 & 0\end{array}\right]$} & {$[* * *]$} & Adekvátní nebo přiměřený \\
\hline 4 & [ 1 ] & {$[* * * *]$} & Dobrý \\
\hline 5 & [ 2 ] & {$[* * * * *]$} & Vynikající \\
\hline & & $\begin{array}{c}\text { [N.r.i.o.r] * (pouze pro } \\
\text { aktualizace) }\end{array}$ & $\begin{array}{l}\text { Položka nebyla v původní } \\
\text { recenzi posuzována }\end{array}$ \\
\hline
\end{tabular}

V této části má být provedeno více hodnocení různých aspektů nebo atributů dokumentace dodávané s nástrojem (nebo balíkem). Termín „dokumentace“ byl vybrán, aby pokrýval všechny ty materiály dodávané s nástrojem nebo snadno dostupné kvalifikovanému uživateli: např. manual administrátora; technické př́ručky; brožury s normami; dodatky k manuálu; aktualizace od vydavatelů/dodavatelů atd.

Položky mají být posuzovány n/a nebo 0 až 5 (poloviční rating je přijatelný)

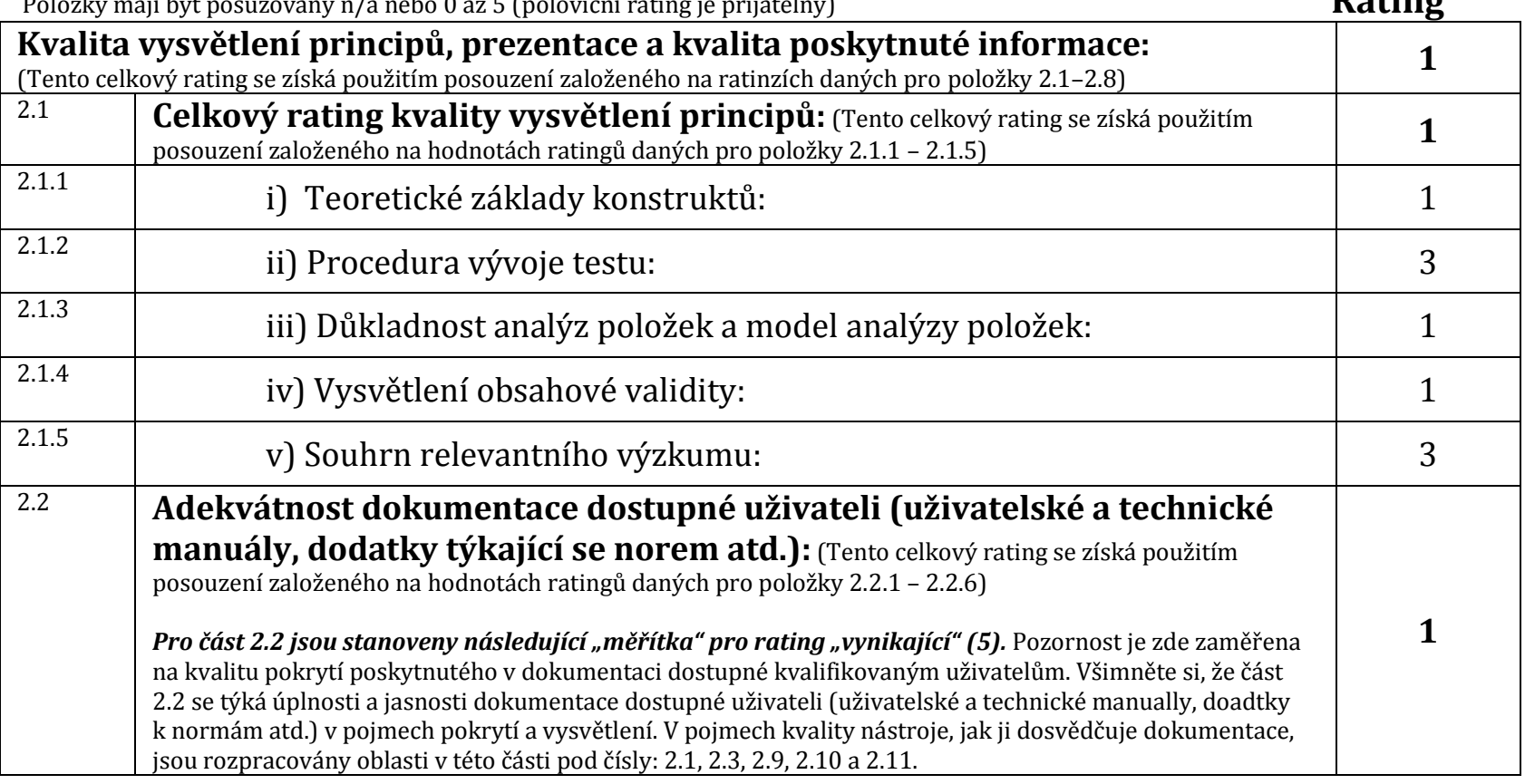




\begin{tabular}{|c|c|c|}
\hline 2.2 .1 & $\begin{array}{l}\text { Principy: [viz 2.1] } \\
\text { Dobře argumentovaný a jasně prezentovaný popis toho, co má podle návrhu měřit a proč byl zkonstruován } \\
\text { tak, jak je. }\end{array}$ & 3 \\
\hline 2.2 .2 & $\begin{array}{l}\text { Vývoj: } \\
\text { Úplné detaily týkající se zdrojů položek, pilotáže, analýz položek, srovnávacích studií a změn prováděných v } \\
\text { prüběhu vývojových pokusú. }\end{array}$ & 3 \\
\hline 2.2 .3 & $\begin{array}{l}\text { Standardizace: } \\
\text { Jasné a detailní informace poskytnuté o velikostech a zdrojích standardizačního souboru a standardizační } \\
\text { proceduře. }\end{array}$ & 1 \\
\hline 2.2 .4 & $\begin{array}{l}\text { Normy: } \\
\text { Jasné a detailní informace poskytnuté o velikostech a zdrojích normalizačních skupin, podmínkách vyšetření } \\
\text { atd. }\end{array}$ & 1 \\
\hline 2.2 .5 & $\begin{array}{l}\text { Reliabilita: } \\
\text { Dobré vysvětlení reliability a široký rozsah měr vnitřní konsistence a retestu spolu s vysvětlením jejich } \\
\text { relevance a zobecnitelnosti nástroje vyšetř̌ení. }\end{array}$ & 1 \\
\hline 2.2 .6 & $\begin{array}{l}\text { Validita: } \\
\text { Dobré vysvětlení validity spolu s širokou škálou studií jasně a poctivě popsaných. }\end{array}$ & 1 \\
\hline 2.3 & $\begin{array}{l}\text { Kvalita procedurálních instrukcí poskytnutých uživateli: (Tento celkový rating se } \\
\text { získá s použitím posouzení na základě hodnot ratingů daných pro položky } 2.3 .1-2.3 .7 \text { ) }\end{array}$ & 3 \\
\hline 2.3 .1 & $\begin{array}{l}\text { Pro administraci testu: } \\
\text { Poskytnutá jasná a detailní vysvětlení a procedurální průvodce krok za krokem spolu s dobrými radami } \\
\text { týkajícícmi se otázek uchazeču a problémových situací. }\end{array}$ & 3 \\
\hline 2.3 .2 & $\begin{array}{l}\text { Pro skórování testu, normy atd:: } \\
\text { Poskytnuté jasné a detailní informace spolu s popsanými kontrolami pro vyhnutí se možným chybám } \\
\text { skórování. }\end{array}$ & 1 \\
\hline 2.3 .3 & $\begin{array}{l}\text { Pro interpretaci a vytváření zpráv: } \\
\text { Detailní doporučení týkající se interpretace různých skórů, chápání normativních měr a zacházení se vztahy } \\
\text { mezi různými škálami, s množstvím ilustrativních příkladů a př́ípadových studií. }\end{array}$ & 3 \\
\hline 2.3 .4 & $\begin{array}{l}\text { Pro poskytnutí zpětné vazby a debriefingu respondentům testu a dalším: } \\
\text { Detailní doporučení, jak prezentovat zpětnou vazbu uchazečum. }\end{array}$ & 1 \\
\hline 2.3 .5 & $\begin{array}{l}\text { Pro poskytování dobrých praktických témat týkajících se poctivosti a } \\
\text { zkreslení: } \\
\text { Uvedení detailních informací o studiích sexuálního a etnického zkreslení s relevantními varováními týkajícími } \\
\text { se použivání a zobecňování validit. }\end{array}$ & 3 \\
\hline 2.3 .6 & $\begin{array}{l}\text { Omezení používání: } \\
\text { Jasné popisy, kdo by měl a kdo by neměl být vyšetřován spolu s dobře vysvětlenými odůvodněními těchto } \\
\text { omezení (např. typy nezpůsobilostí, požadované úrovně gramotnosti atd.). }\end{array}$ & 1 \\
\hline 2.3 .7 & $\begin{array}{l}\text { Reference a podpůrné materiály: } \\
\text { Detailní odkazy na relevantní podpůrnou akademickou literature a křížové odkazy na další příbuzné } \\
\text { materially týkající se diagnostických nástrojů. }\end{array}$ & 3 \\
\hline $\begin{array}{l}\text { Kval } \\
\text { (Tentc }\end{array}$ & $\begin{array}{l}\text { Materiálů: } \\
\text { ový rating se získá použitím posouzení založeného na hodnotách ratingů pro položky } 2.4-2.8 \text { ) }\end{array}$ & 0 \\
\hline 2.4 & $\begin{array}{l}\text { Všeobecná kvalita materiálů testu } \\
\text { (testové brožury, odpověd'ové archy, testové objekty, software atd.): }\end{array}$ & 3 \\
\hline 2.5 & Kvalita lokální adaptace testu (pokud byl test přeložen a adaptován do místního jazyka): & 0 \\
\hline 2.6 & Snadnost, s jakou může respondent testu porozumět úkolu: & 5 \\
\hline 2.7 & $\begin{array}{l}\text { Snadnost, s jakou mohou být respondentem testu tvořeny reakce nebo } \\
\text { odpovědi: }\end{array}$ & 5 \\
\hline 2.8 & Kvalita položek: & 0 \\
\hline \multicolumn{3}{|c|}{$\begin{array}{l}\text { Recenzentovy komentáře týkající se dokumentace: } \\
\text { (komentáře principů, designu, vývoje testu a jeho přijatelnosti) }\end{array}$} \\
\hline \multicolumn{3}{|c|}{$\begin{array}{l}\text { Největší slabinou české adaptace BDI-II je nedostatek poskytnutých informací. Autoři } \\
\text { manuálu (Preiss a Vacíř, 1999) sice poměrně detailně a přesně popisují účel, pro který by } \\
\text { nástroj vytvořen, historický vývoj různých verzí a jejich korelace s podobnými nástroji, } \\
\text { avšak k samotné české adaptaci uvádějí pouze jednu standardizační studii, z jejíchž } \\
\text { výsledků nelze stanovit lokální normy. Na základě předložených informací proto nelze } \\
\text { posoudit kvalitu české adaptace BDI-II, ačkoliv si bezpochyby zachovala jednoduchost a } \\
\text { srozumitelnost originálu. }\end{array}$} \\
\hline
\end{tabular}




\section{Č́st 7: \\ Hodnocení norem, reliability a validity}

\section{Informace o normách nebo referenční skupině}

\begin{tabular}{|c|c|c|}
\hline 2.9 & Celková adekvátnost: & 1 \\
\hline 2.9 .1 & $\begin{array}{cl}\begin{array}{c}\text { Vhodnost pro lokální použití, at' už pro lokální nebo mezinárodní normy: } \\
{[\mathrm{n} / \mathrm{a}]}\end{array} & \begin{array}{l}\text { Nepoužitelné } \\
0\end{array} \\
\begin{array}{l}\text { Žádná informace nepodána. } \\
3\end{array} & \begin{array}{l}\text { Není lokálně relevantní (např. nevhodné zahraniční výběry). } \\
\text { Lokální výběr z obecné populace nebo nelokální normy, které lze } \\
\text { použít s varováním. }\end{array} \\
& \begin{array}{l}\text { Výběry lokální země nebo relevantní mezinárodní výběry s dobrou } \\
\text { relevancí pro zamýšlenou aplikaci. }\end{array} \\
5 & \begin{array}{l}\text { Výběry lokální země nebo relevantní mezinárodní výběry vybrané z } \\
\text { dobře definovaných výběrủ z relevantních aplikačních oblastí. }\end{array}\end{array}$ & 1 \\
\hline 2.9 .2 & $\begin{array}{ll}\begin{array}{l}\text { Vhodnost pro zamýšlené aplikace: } \\
{[\mathrm{n} / \mathrm{a}]}\end{array} & \begin{array}{l}\text { Nepoužitelné } \\
0\end{array} \\
1 & \text { Žádná informace nepodána. } \\
3 & \begin{array}{l}\text { Norma nebo normy nejsou adekvátní pro zamýšlené aplikace. } \\
\text { Adekvátní normy pro obecnou populaci a/nebo rozmezí normativních }\end{array} \\
4 & \text { tabulek. } \\
5 & \begin{array}{l}\text { Dobré rozmezí normativních tabulek. } \\
\text { Vynikající rozmezí výběrově relevantních norem vztahujících se k věku } \\
\text { a pohlaví, s informacemi o dalších rozdílech v rámci skupin (např. } \\
\text { směs etnických skupin). }\end{array} \\
\end{array}$ & 1 \\
\hline 2.9 .3 & $\begin{array}{ll}\begin{array}{l}\text { Velikosti výběrů: } \\
{[\mathrm{n} / \mathrm{a}]}\end{array} & \text { Nepoužitelné } \\
0 & \text { Žádná informace nepodána. } \\
1 & \text { Neadekvátní výběry (např. méně než 150). } \\
3 & \text { Adekvátní výběry (např. 150-300). } \\
4 & \text { Velké výběry (např. 300-1000). } \\
5 & \text { Velmi velké výběry (např. 1000+). } \\
\end{array}$ & 1 \\
\hline 2.9 .4 & $\begin{array}{cl}\text { Procedury použité při výběru souboru: } \\
\square & \text { Žádná informace neposkytnuta } \\
\square & \text { Reprezentativní populaci [sumarizujte kritéria] } \\
\square & \text { Nahodilá } \\
\square & \text { Náhodná }\end{array}$ & 1 \\
\hline 2.9 .5 & $\begin{array}{l}\text { Kvalita informací poskytnutých o minoritní/chráněné skupině, rozdílech, } \\
\text { vlivech věku, rodu atd.: } \\
\begin{array}{cl}{[\mathrm{n} / \mathrm{a}]} & \text { Nepoužitelné } \\
0 & \text { Žádná informace nepodána. } \\
1 & \text { Neadekvátní informace. } \\
3 & \text { Adekvátní obecné informace s minimální analýzou. } \\
4 & \text { Dobré popisy a analýzy skupin a rozdílů } \\
5 & \text { Vynikající série analýz a diskuse o relevantních tématech vztahujících } \\
& \text { se k použití a interpretaci. }\end{array}\end{array}$ & 0 \\
\hline
\end{tabular}


2.9.6 Komentáře recenzentů k normám: Stručná zpráva o normách a jejich historii, včetně informací o doporučeních učiněných vydavatelem/autorem pro aktualizaci norem obvyklým způsobem.

Standardizace originální anglické verze BDI-II proběhla na vzorku 500 pacientů a 120 studentů. Na základě toho byly pro BDI-II navrženy cut-off skóry $0-13$ pro minimální nebo žádnou depresi, 14-19 pro mírnou depresi, 20-28 pro střední a 29-63 pro těžkou depresi. V naprosté většině studií dosáhla senzitivita BDI-II alespoň hranice $0,7 \mathrm{~s}$ hodnotami pohybujícími se nejčastěji v rozmezí 0,8 až 0,9 (Wang a Gorenstein, 2013). Vysoká senzitivita je značnou výhodou BDI-II jakožto screeningového nástroje, ačkoliv je to vykoupeno nižší specificitou (cca 0,7-0,8; Beck, Steer a Brown, 1996; Warmenhoven et al., 2012).

Českou adaptaci BDI-II vytvořili Preiss a Vacír (1999). Samotný překlad byl čtyřikrát revidován a zkušebně použit na několika pacientech VFN Praha a ÚVN Praha. Žádné další informace o klinickém vzorku či proceduře autoři neuvádějí. Standardizační vzorek pak tvořilo 60 mladých českých mužů, kteří nastoupili na základní vojenskou službu. Průměrné skóre deprese u nich bylo lehce zvýšené $(m=10,26 ; \mathrm{s}=7,02)$, což autoři přičítají změně denního režimu, která mohla zapř́íčinit zvýšené skóry v oblasti somatických symptomů deprese. Zvýšení však může být i důsledkem českého překladu.

Hlavním úkolem této standardizace bylo identifikovat nesrozumitelné položky. Vzhledem k charakteristikám výzkumného souboru a absenci standardizačního klinického vzorku je nemožné pro českou adaptaci BDI-II stanovit lokální normy. Autoři (tamtéž) se sice ohledně norem odkazují také na jiné české studie, nicméně tyto studie byly prováděny s adaptacemi předchozích verzí BDI, a tudíž je pro standardizaci BDI-II nelze využít. Možná i proto se Preiss a Vacíř ve svém manuálu přiklánějí k interpretaci skórů podle Becka, Steera a Browna (1996) a ve shodě s nimi navrhují cut-off skór $16 / 17$ s poznámkou, že skórům v rozmezí 10-16 by měla být věnována zvýšená pozornost. Takovéto nekritické přejímání zahraničních norem na českou populaci je však samo o sobě nedostačující.

\section{Validita}

\begin{tabular}{|c|c|c|}
\hline 2.10 & $\begin{array}{l}\text { Celková adekvátnost: (Tento celkový rating se získá na základě posouzení hodnot ratingů } \\
\text { daných v položkách } 2.10 .1-2.10 .2 .4 \text {. Neprůměrujte pouze čísla, abyste získali celkový rating. } \\
\text { Obvykle bude roven bud' konstruktové validitě nebo validitě vztahující se ke kritériu, podle } \\
\text { toho, která z nich je vyšší.) }\end{array}$ & $\mathbf{0}$ \\
\hline 2.10 .1 & $\begin{array}{l}\text { Konstruktová validita - celková adekvátnost } \\
\text { (Tento celkový rating se získá na základě posouzení hodnot ratingů daných v položkách } \\
\text { 2.10.1.2 - 2.10.1.6. Neprůměrujte pouze čísla, abyste tento celkový rating získali.) }\end{array}$ & 0 \\
\hline 2.10.1.1 & 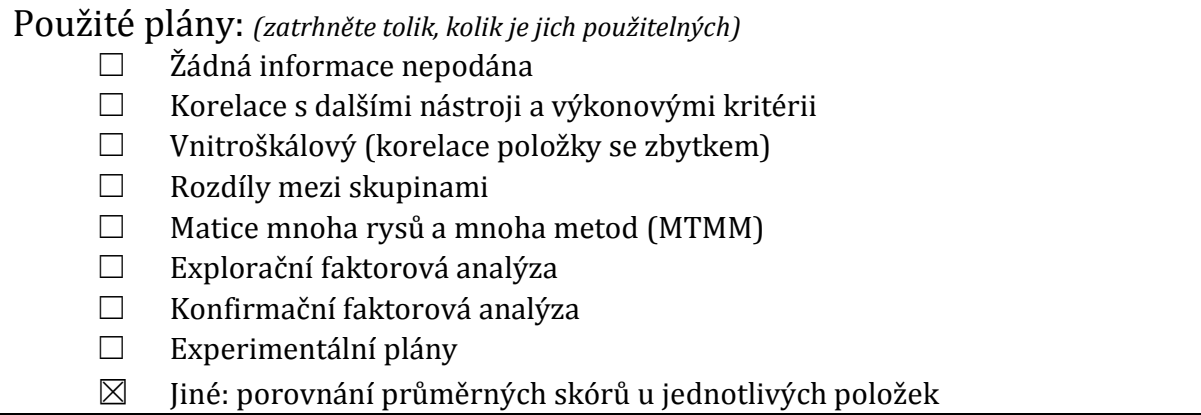 & \\
\hline 2.10 .1 .2 & \begin{tabular}{cl}
\multicolumn{2}{l}{ Velikosti výběrů: } \\
0 & Žádná informace neposkytnuta. \\
1 & Jedna neadekvátní studie (např. velikost výběru menší než 100). \\
3 & Jedna adekvátní studie (např. velikost výběru 100-200). \\
4 & Více než jedna adekvátní nebo velká studie. \\
5 & Dobrá série adekvátních až rozsáhlých studií.
\end{tabular} & 1 \\
\hline
\end{tabular}




\begin{tabular}{|c|c|c|c|}
\hline 2.10 .1 .3 & $\begin{array}{c}\text { Procedul } \\
\quad \mathbb{} \\
\square \\
\square \\
\square\end{array}$ & $\begin{array}{l}\text { ra výběru souboru: (vyberte jednu) } \\
\text { Žadná informace neposkytnuta } \\
\text { Reprezentativní vǔči populaci [sumarizujte kritéria] } \\
\text { Nahodilá } \\
\text { Náhodná }\end{array}$ & \\
\hline \begin{tabular}{|l|l}
2.10 .1 .4 \\
\end{tabular} & $\begin{array}{c}\text { Medián a } \\
0 \\
1 \\
3 \\
4 \\
5 \\
\end{array}$ & $\begin{array}{l}\text { rozsah korelací mezi testem a dalšími podobnými testy: } \\
\text { Žádná informace neposkytnuta. } \\
\text { Neadekvátní }(\mathrm{r}<0.55) \text {. } \\
\text { Adekvátní }(0.55<\mathrm{r}<0.65) \text {. } \\
\text { Dobrý }(0.65<\mathrm{r}<0.75) . \\
\text { Vynikajíí }(\mathrm{r}>0.75)\end{array}$ & 0 \\
\hline 2.10 .1 .5 & $\begin{array}{c}\text { Kvalita } \mathrm{n} \\
0 \\
1 \\
3 \\
4 \\
5\end{array}$ & $\begin{array}{l}\text { lástrojů jako kritérií nebo markerů: } \\
\text { Žádná informace neposkytnuta. } \\
\text { Poskytnuta neadekvátní informace. } \\
\text { Adekvátní kvalita. } \\
\text { Dobrá kvalita. } \\
\text { Vynikající kvalita s širokým rozsahem relevantních markerů pro } \\
\text { konvergentní a divergentní validizaci. } \\
\end{array}$ & 0 \\
\hline 2.10 .1 .6 & $\begin{array}{c}\text { Analýzy } \\
{[\mathrm{N} / \mathrm{A}} \\
0-5 \\
\end{array}$ & $\begin{array}{l}\text { diferenciálního fungování položek (DIF): } \\
\text { Nepoužitelné } \\
\text { hodnocení kvality DIF analýzy }\end{array}$ & 0 \\
\hline $\begin{array}{l}2.10 .2 \\
\end{array}$ & $\begin{array}{l}\text { Validita } \\
\text { (Tento celkc } \\
2.11 .1-2.1 \text {. }\end{array}$ & $\begin{array}{l}\text { vztahující se ke kritériu - celková adekvátnost } \\
\text { ový rating se získá na základě posouzení hodnot ratingů daných v položkách } \\
\text { 0.2.4. Neprůměrujte pouze čísla, abyste získali celkový rating.) }\end{array}$ & $\mathbf{0}$ \\
\hline 2.10.2.1 & 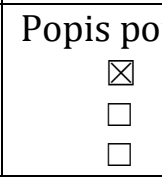 & $\begin{array}{l}\text { užitých kritérií a charakteristik populací: (zatrhněte tolik, kolik je por } \\
\text { Souběžná } \\
\text { Prediktivní } \\
\text { Postdiktivní }\end{array}$ & \\
\hline 2.10 .2 .2 & $\begin{array}{l}\text { Velikos } \\
0 \\
1 \\
3 \\
4 \\
5 \\
\end{array}$ & $\begin{array}{l}\text { ti výběrů: } \\
\text { Žádná informace neposkytnuta. } \\
\text { Jedna neadekvátní studie (napřs. velikost výběru menší než 100). } \\
\text { Jedna adekvátní studie (např. velikost výběru 100-200). } \\
\text { Jedna velká nebo vice než jedna adekvátně rozsáhlá studie. } \\
\text { Dobrá série adekvátních až rozsáhlých studií. }\end{array}$ & 1 \\
\hline 2.10 .2 .3 & $\begin{array}{c}\text { Procedul } \\
\text { (vyberte je } \\
\square \\
\square \\
\square \\
\square \\
\end{array}$ & $\begin{array}{l}\text { ra výběru souboru: } \\
\text { dnu) } \\
\text { Žádná informace neposkytnuta } \\
\text { Účelná nebo reprezentativní } \\
\text { Nahodilá } \\
\text { Náhodná }\end{array}$ & \\
\hline 2.10 .2 .4 & $\begin{array}{c}\text { Medián a } \\
0 \\
1 \\
3 \\
4 \\
5\end{array}$ & $\begin{array}{l}\text { rozsah korelací mezi testem a kritérii: } \\
\text { Žádná informace neposkytnuta. } \\
\text { Neadekvátní (napřr. } \mathrm{r}<0.2 \text { ). } \\
\text { Adekvátní (napřr. } 0.2<\mathrm{r}<0.35 \text { ). } \\
\text { Dobrý (napřr. } 0.35<\mathrm{r}<0.50 \text { ). } \\
\text { Vynikající (např. } \mathrm{r}>0.50 \text { ) }\end{array}$ & 0 \\
\hline 2.10 .3 & Komentá & ře recenzenta týkající se validity: & \\
\hline $\begin{array}{l}\text { Kriterić } \\
\text { ovlivňc } \\
\text { Obsaho } \\
\text { teoretic } \\
\text { známýc } \\
\text { přiblíže } \\
\text { sympto } \\
\text { Konstr } \\
\text { analýzy } \\
\text { Subica } \\
\text { a some }\end{array}$ & $\begin{array}{l}\text { lní validi } \\
\text { vána senz } \\
\text { vou valid } \\
\text { kého kon } \\
\text { h depresiy } \\
\text { ní se dią } \\
\text { mům depr } \\
\text { ktová va } \\
\text { Na toto } \\
\text { et al., } 201 \\
\text { tickým fo }\end{array}$ & $\begin{array}{l}\text { ta velmi závisí na nastavených cut-off skórech, nebot' } \\
\text { itivita a specificita nástroje. } \\
\text { itu není u BDI-II lehké zhodnotit, nebot' metoda nevych } \\
\text { ceptu deprese. Obsahové univerzum položek bylo vytvořen } \\
\text { vních symptomů, ovšem existují názory (Wang a Gorenstei } \\
\text { gnostice podle DSM-IV přišlo BDI-II o část svojí senzi } \\
\text { ese a tím pádem došlo i k zúžení obsahové validity. } \\
\text { lidita původní škály je ověřována především pomocí kc } \\
\text { téma bylo realizováno více výzkumů (např. Steer, Ball, R } \\
\text { 4) a jako nejlepší se ukázala být dvoufaktorová struktura s k } \\
\text { aktorem. Některé výzkumy navrhují i trojfaktorový mo }\end{array}$ & $\begin{array}{l}\text { e přímo } \\
\text { jednoho } \\
\text { ebecně } \\
\text { snahou o } \\
\text { lěkterým } \\
\text { aktorové } \\
\text { k, 1999; } \\
\text { ektivním }\end{array}$ \\
\hline
\end{tabular}


afektivním faktorem zvlášst' (Wang a Gorenstein, 2013).

Souběžnou validitu vykazuje originální BDI-II středními až silnými korelacemi s množstvím jiných nástrojů pro měření deprese, za všechny např. Center for Epidemiologic Studies of Depression (CES-D), Hamilton Depression Rating Scale (HAM-D) nebo Zung Self-Rating Depression Scale (SDS) (více viz Wang a Gorenstein, 2013).

Konvergentní validitu angické verze dokazují středně silné korelace s nástroji měřícími úzkost (tamtéž), která většinou bývá součástí deprese. $Z$ toho ovšem plyne i nižší diskriminační validita BDI-II mezi depresí a pouhou úzkostí. Řada studií uvádí, že originální BDI-II také nadhodnocuje depresi u lidí trpících chronickým únavovým syndromem (Brown, Kaplan a Jason, 2011), obezitou (Hayden, Dixon, Dixon a O'Brien, 2010), Huntingtonovou chorobou (Rickards et al., 2011) nebo třeba žloutenkou (Patterson et al., 2011). Důvodem jsou některé somatické projevy podobné symptomům deprese.

U české adaptace autoři (Preiss a Vacíř, 1999) sice na základě standardizační studie nezjistili žádné vážnější narušení validity $\mathrm{v}$ důsledku překladu, ale neuvádějí ani žádné argumenty ve prospěch obsahové, kriteriální, konstruktové, souběžné, prediktivní ani faktorové validity. Senzitivita ani specificita nebyly zjišt'ovány. $Z$ tohoto důvodu není možné posoudit validitu české adaptace, ačkoliv lze předpokládat, že se blíží validitě originálu.

\section{Reliabilita}

\begin{tabular}{|c|c|c|}
\hline 2.11 & $\begin{array}{l}\text { Celková adekvátnost: } \\
\text { (Tento celkový rating se získá na základě posouzení hodnot ratingů daných v položkách 2.11.1-2.10.2.4. } \\
\text { Neprüměrujte pouze čísla, abyste získali celkový rating.) }\end{array}$ & $\mathbf{0}$ \\
\hline 2.11 .1$. & $\begin{array}{l}\text { Poskytnutá data týkající se reliability: (vyberte jednu možnost) } \\
\square \quad \text { Uveden pouze jeden koeficient reliability } \\
\square \quad \text { Uveden pouze jeden odhad standardní chyby měření } \\
\square \quad \text { Koeficienty reliability pro několik různých skupin } \\
\square \quad \text { Standardní chyba měření uvedená pro několik různých skupin } \\
\bigotimes \quad \text { Jiné: žádná data neposkytnuta }\end{array}$ & \\
\hline 2.11 .1 & Vnitřní konzistence: & \\
\hline 2.11.1.1 & $\begin{array}{cl}\text { Velikost výběru: } \\
0 & \text { Neposkytnuta žádná informace. } \\
1 & \text { Jedna neadekvátní studie (např. rozsah výběru menší než 100). } \\
3 & \text { Jedna adekvátní studie (např. rozsah výběru 100-200). } \\
4 & \text { Jedna rozsáhlá nebo vice než jedna adekvátně rozsáhlá studie. } \\
5 & \text { Dobrá série adekvátních až rozsáhlých studií. } \\
{[\mathrm{N} / \mathrm{A}]} & \text { Nepoužitelné. } \\
\end{array}$ & 1 \\
\hline 2.11 .1 .2 & $\begin{array}{cl}\text { Medián koeficientů: } \\
0 & \text { Neposkytnuta žádná informace. } \\
1 & \text { Neadekvátní (např. } r<0.7 \text { ) } \\
3 & \text { Adekvátní (např. } r=0.7 \text { až } 0.79 \text { ) } \\
4 & \text { Dobrý (např. } r=0.8 \text { až } 0.89 \text { ) } \\
5 & \text { Vynikající (např. } r>0.9 \text { ) } \\
{[\mathrm{N} / \mathrm{A}]} & \text { Nepoužitelné. } \\
\end{array}$ & 0 \\
\hline 2.11 .2 & Testová-retestová stabilita: & \\
\hline 2.11 .2 .1 & $\begin{array}{cl}\text { Rozsah výběru: } & \\
0 & \text { Neposkytnuta žádná informace. } \\
1 & \text { Jedna neadekvátní studie (např. rozsah výběru menší než 100). } \\
3 & \text { Jedna adekvátní studie (např. rozsah výběru 100-200). } \\
4 & \text { Jedna rozsáhlá nebo vice než jedna adekvátně rozsáhlá studie. } \\
5 & \text { Dobrá série adekvátních až rozsáhlých studií. } \\
\end{array}$ & 1 \\
\hline 2.11 .2 .2 & $\begin{array}{cl}\text { Medián koeficientů: } \\
0 & \text { Neposkytnuta žádná informace. } \\
1 & \text { Neadekvátní (např. } \mathrm{r}<0.6 \text { ) } \\
3 & \text { Adekvátní (např. } \mathrm{r}=0.6 \text { až } 0.69 \text { ) } \\
4 & \text { Dobrý (nap̌̌r. } \mathrm{r}=0.7 \text { až } 0.79 \text { ) } \\
5 & \text { Vynikající (např. } \mathrm{r}>0.8 \text { ) }\end{array}$ & 0 \\
\hline
\end{tabular}




\begin{tabular}{|c|c|c|c|}
\hline 2.11 .3 & Reliabilita jako & kvivalence: & \\
\hline 2.11 .3 .1 & $\begin{array}{l}\text { Rozsah výběru: } \\
0 \\
1 \\
3 \\
4 \\
5 \\
{[\mathrm{~N} / \mathrm{A}]}\end{array}$ & $\begin{array}{l}\text { Neposkytnuta žádná informace. } \\
\text { Jedna neadekvátní studie (napřr. rozsah výběru menší než 100). } \\
\text { Jedna adekvátní studie (napřr. rozsah výběru 100-200). } \\
\text { Jedna rozsáhlá nebo vice než jedna adekvátně rozsáhlá studie. } \\
\text { Dobrá série adekvátních až rozsáhlých studií. } \\
\text { Nepoužitelné. }\end{array}$ & 1 \\
\hline 2.11 .3 .2 & $\begin{array}{l}\text { Medián koeficie } \\
\quad 0 \\
1 \\
3 \\
4 \\
5 \\
{[\mathrm{~N} / \mathrm{A}]} \\
\end{array}$ & $\begin{array}{l}\text { atů: } \\
\text { Neposkytnuta žádná informace. } \\
\text { Neadekvátní (např. } r<0.6 \text { ) } \\
\text { Adekvátní (napřr. } r=0.6 \text { až } 0.69 \text { ) } \\
\text { Dobrý (napřr. } r=0.7 \text { až } 0.79 \text { ) } \\
\text { Vynikající (např. r }>0.8 \text { ) } \\
\text { Nepoužitelné }\end{array}$ & 0 \\
\hline \multicolumn{4}{|c|}{$\begin{array}{l}\text { 2.11.4 Komentáŕre recenzentů k reliabilitě: } \\
\text { - Komentujte intervaly spolehlivosti pro koeficienty reliability } \\
\text { - Uved'te Spearmanovy-Brownovy ekvivalenty }\end{array}$} \\
\hline \multicolumn{4}{|c|}{$\begin{array}{l}\text { Beck, Steer a Brown, (1996) uvádějí, že test-retestová reliabilita po } 7 \text { dnech činila } 0,93 \text { a vnitřní } \\
\text { konzistence škály dosáhla hodnoty 0,92. Ve většině ostatních výzkumů se Cronbachova alfa } \\
\text { pohybuje kolem 0,9 (rozsah 0,83-0,96; pro detailnější přehled viz Wang a Gorenstein, 2013). } \\
\text { Autoři české adaptace (Preiss a Vacír, 1999) odhady reliability neuvádějí. }\end{array}$} \\
\hline
\end{tabular}

\section{Část 9:}

\section{Závěrečné hodnocení:}

\subsection{Hodnotící zpráva testu:}

Tato část by měla obsahovat stručné, jasně obhájené posouzení nástroje/produktu. Mělo by popisovat jeho pro a proti a poskytnout určitá obecná doporučení týkající se toho, jak a kdy by se měl používat - spolu s varováními (kde jsou potřebná) týkajícími se případů, kde by se používat neměl.

Mezi největší přednosti BDI-II patří zejména jednoduchost, rychlost administrace a vyhodnocování. Zároveň se jedná o světově rozšířený a uznávaný nástroj, který byl přeložen do mnoha jazyků a má normy pro různé populace, ačkoliv je nutné ještě lépe prozkoumat psychometrické vlastnosti české adaptace. Jelikož BDI-II měří depresi jakožto stav, lze ho využít i pro pravidelnou kontrolu nebo detekci změn stavu pacientů. Zaměření se na skóry jednotlivých položek může být navíc užitečným vodítkem při tvorbě celkového obrazu deprese. Nevýhodu představuje vysoká zjevná validita. Uživatel může odpovědi snadno vědomě ovlivnit, a proto by měl administrátor věnovat pozornost extrémně nízkým nebo vysokým celkovým skórům, zvláště existuje-li předpoklad, že by uživatel mohl o svém stavu lhát. V neposlední řadě je důležité mít na paměti, že BDI-II není vhodným nástrojem pro stanovení diagnózy deprese, ale lze ho použít ke screeningu či měření aktuální závažnosti deprese.

Česká adaptace BDI-II (Preiss a Vacíř, 1999) ve své podstatě představuje pouze překlad původního znění spolu s hrubým ověřením validity na základě průměrných skórů položek. I když by překlad sám o sobě neměl narušit psychometrické vlastnosti nástroje, je nutné provést důkladnější standardizaci. Bez ní není možné blíže ověřit reliabilitu či validitu nástroje, ani nastavit normy pro českou populaci, což značně omezuje možnosti klinického využití. 


\subsection{Závěry:}

BDI-II představuje jednoduchý a psychometricky kvalitní nástroj pro zjišt’ování závažnosti deprese. $V$ př́ipadě české adaptace však nejsou $\mathrm{k}$ dispozici důkazy o validitě ani reliabilitě a při interpretaci výsledků se používají zahraniční normy. Dokud neproběhne důkladnější standardizace, odhad validity a reliability, stanovení lokálních norem a zjištění senzitivity a specificity, je tento nástroj lepší používat pouze pro výzkumné účely.

\subsection{Doporučení (vyberte jedno)}

Všechny následující charakteristiky uvedené níže by měly mít ratingy [n/a], [2], [4], [5], pokud by měl být nástroj "doporučen" pro obecné použití (hodnocení 5 nebo 6):

[2.9] Normy a referenční skupiny

[2.10.1] Konstruktová validita

[2.10.2] Kriteriální validita

[2.11] Reliabilita - celková

[2.12] Počítačově generované

zprávy

Pokud má kterýkoli z výše uvedených ratingů hodnotu [] nebo [1], nástroj by měl být klasifikován pod doporučením 1, 2, 3 nebo 4, nebo klasifikován pod doporučením 7 "jiné" s adekvátním vysvětlením.
1 Pouze výzkumný nástroj. Ne pro užití v praxi.

2 Vhodný pouze pro užití expertním uživatelem za pečlivě kontrolovaných podmínek nebo ve velmi omezených aplikačních oblastech

3 Vhodný pro použití pod supervizí $\mathrm{v}$ aplikační(ch) oblasti(ech) definovaných distributorem, libovolnými uživateli s obecnými kompetencemi pro používání a administraci testů

4 Vyžaduje další vývoj. Vhodný pouze pro použití ve výzkumu.

5 Vhodný pro používání vaplikační(ch) oblasti(ech) definovaných distributorem, uživateli testů, kteří splňují speciální kvalifikační požadavky distributora

6 Vhodný pro sebevyšetření bez supervise v aplikační(ch) oblasti(ech) definovaných distributorem

7 Jiné: Původní metoda splňuje podmínky na bod 5. Česká adaptace je aktuálně na bodu 4 , v závislosti na výsledcích další standardizace potenciálně také bod 5 .

\section{Odkazy k poznámkám a bibliografie}

Beck, A.T., Rush, A.J., Shaw, B.F., Emery, G. (1979). Cognitive therapy of depression. New York: Guilford.

Beck, A.T., Steer, R.A., Ball, R., Ranieri, W.F. (1996). Comparison of Beck Depression Inventories -IA and -II in Psychiatric Outpatients. Journal of Personality Assessment, 67(3), 588-597.

Beck, A.T., Steer, R.A., Brown, G.K. (1996). Manual for the Beck Depression Inventory-II. San Antonio, TX: Psychological Corporation.

Beck, A.T., Ward, C.H., Mendelson, M., Mock, J.E., Erbaugh, J.K. (1961). An inventory for measuring depression. Archives of general psychiatry, 4(6), 561-571.

Brown, M., Kaplan, C., Jason, L. (2011). Factor analysis of the Beck Depression Inventory-II with patiens with chronic fatigue syndrome. Journal of Health Psychology, 17(6), 799808.

Furlanetto, L.M., Mendlowicz, M.V., Romildo, B.J. (2005). The validity of the Beck Depression Inventory-Short Form as a screening and diagnostic instrument for moderate and severe depression in medical inpatients. Journal of Affective Disorders, 86(1), 87-91. 
Hayden, M.J., Dixon, J.B., Dixon, M.E., O’Brien, P.E. (2010). Confirmatory factor analysis of the Beck Depression Inventory in obese individuals seeking surgery. Obesity Surgery, 20, 432-439.

Ippen, C. G., Wong, C. (n.d.). Beck Depression Inventory-Second Edition. Staženo 7. 10. $2014 \mathrm{z}$ http://www.nctsnet.org/content/beck-depression-inventory-second-edition.

Patterson, A.L., Morasco, B.J., Fuller, B.E., Indest, D.W., Loftis, J.M., Hauser, P. (2011). Screening for depression in patients with hepatitis C using the Beck Depression Inventory-II: do somatic symptoms kompromise validity? General Hospital Psychiatry, 33, 354-362.

Plake, B. S., Impara, J. C. (2001). The fourteenth mental measurements yearbook. Buros Institute of Mental Measurements, University of Nebraska-Lincoln.

Preiss, M., Vacír, K. (1999). BDI-II. Beckova sebeposuzovací škála pro dospělé. Brno: psychodiagnostika.

Rickards, H., De Souza J., Crooks, J., van Walsem, M.R., van Duijn, E., et al. Discriminant analysis of Beck Depression Inventory and Hamilton Rating Scale for Depression in Huntington's disease. Journal of Neuropsychiatry and Clinical Neurosciences, 23, 399402.

Steer, R.A., Ball, R., Ranieri, W.F., Beck, A.T. (1999). Dimensions of the Beck Depression Inventory-II in clinically depressed outpatients. Journal of Clinical Psychology, 55(1), 117-128.

Subica, A.M., Fowler, J.C., Elhai, J.D., Frueh, B.C., Sharp, C., et al. (2014). Factor structure and diagnosis validity of the Beck Depression Inventory-II with adult clinical inpatients: comparison to gold-standard diagnostic interview. Psychological Assessment.

Wang, Y.P., Gorenstein, C. (2013). Psychometric properties of the Beck Depression Inventory-II: a comprehensive review. Revista Brasileira de Psiquiatria, 35, 416-431.

Warmenhoven, F., van Rijswijk, E., Engels, Y., Kan, C., Prins, J., van Weel, C., et al. (2012). The Beck Depression Inventory (BDI-II) and a single screening question as screening tools for depressive disorder in Dutch advanced cancer patients. Supportive Care in Cancer, 20(2), 319-324.

\section{Měřené konstrukty:}

\section{Depresivita}

